Article

\title{
Two New Triterpene Glycosides with Monomethyl Malonate Groups from the Rhizome of Cimifuga foetida $\mathrm{L}$.
}

\section{Li-Rong Sun ${ }^{1,2, *}$, Jian Yan ${ }^{3}$, Lin Zhou ${ }^{1}$, Zhong-Rong Li ${ }^{1}$ and Ming-Hua Qiu ${ }^{1, *}$}

1 State Key Laboratory of Phytochemistry and Plant Resources in West China, Kunming Institute of Botany, the Chinese Academy of Sciences, Kunming 650204, China

2 Department of Neurobiology, Southern Medical University, Guangzhou 510515, China

3 Key Laboratory of Plant Resources Conservation and Sustainable Utilization, South China Botanical Garden, Chinese Academy of Sciences, Guangzhou 510650, China;

E-Mail: yanjian@scbg.ac.cn

* Authors to whom correspondence should be addressed; E-Mails: kmslr@sina.com (L.-R.S.); mhchiu@mail.kib.ac.cn (M.-H.Q.); Tel.: +86 2062789020 (L.-R.S.); +86 8715223327 (M.-H.Q.); Fax: +86 2061648216 (L.-R.S.); +86 8715223255 (M.-H.Q.).

Received: 31 May 2011; in revised form: 27 June 2011 / Accepted: 29 June 2011 /

Published: 5 July 2011

\begin{abstract}
Two new 9,19-cycloartane triterpene glycosides 1-2, together with four known compounds-26-deoxyactein (3), actein (4), 7,8-didehydro-26-deoxyactein (5) and cimiaceroside B (6) - were isolated from the rhizome of Cimicifuga foetida. The new triterpene glycosides were identified as 23-O-methyl-24-deoxy-2'-O-(3"-methylmalonyl)cimiaceroside B (1) and 2'-O-(3"-methylmalonyl)actein (2) based on analysis of their spectral data and chemical reactions.
\end{abstract}

Keywords: Cimicifuga foetida; cycloartane triterpenoid; cimiaceroside; cimifoside

\section{Introduction}

Cimicifuga species are popular Chinese Traditional Medicine, and they are also widely used as a herbal dietary supplement for the relief of symptoms related to menopause [1,2] with a clinical history going back over forty years [3] in the United States and the European Union. Previous investigations 
revealed that triterpene glycosides were the main active components and could be used as marker compounds to standardize the extracts [4]. In our continuing to search on $C$. foetida from different geographic regions, we have separated more than 40 triterpene glycosides [5-11]. In the present investigation on $C$. foetida collected in Lijiang county, Yunnan Province, two new glycosides 1-2, besides the known compounds 26-deoxyactein (3) [12], actein (4) [13], 7,8-didehydro-26-deoxyactein (5) [14] and cimiaceroside B (6) [15] were isolated from it (Figure 1). This report describes the isolation and structure elucidation of the new compounds.

Figure 1. Chemical structures of triterpenoid glycoside from the $C$. foetida.
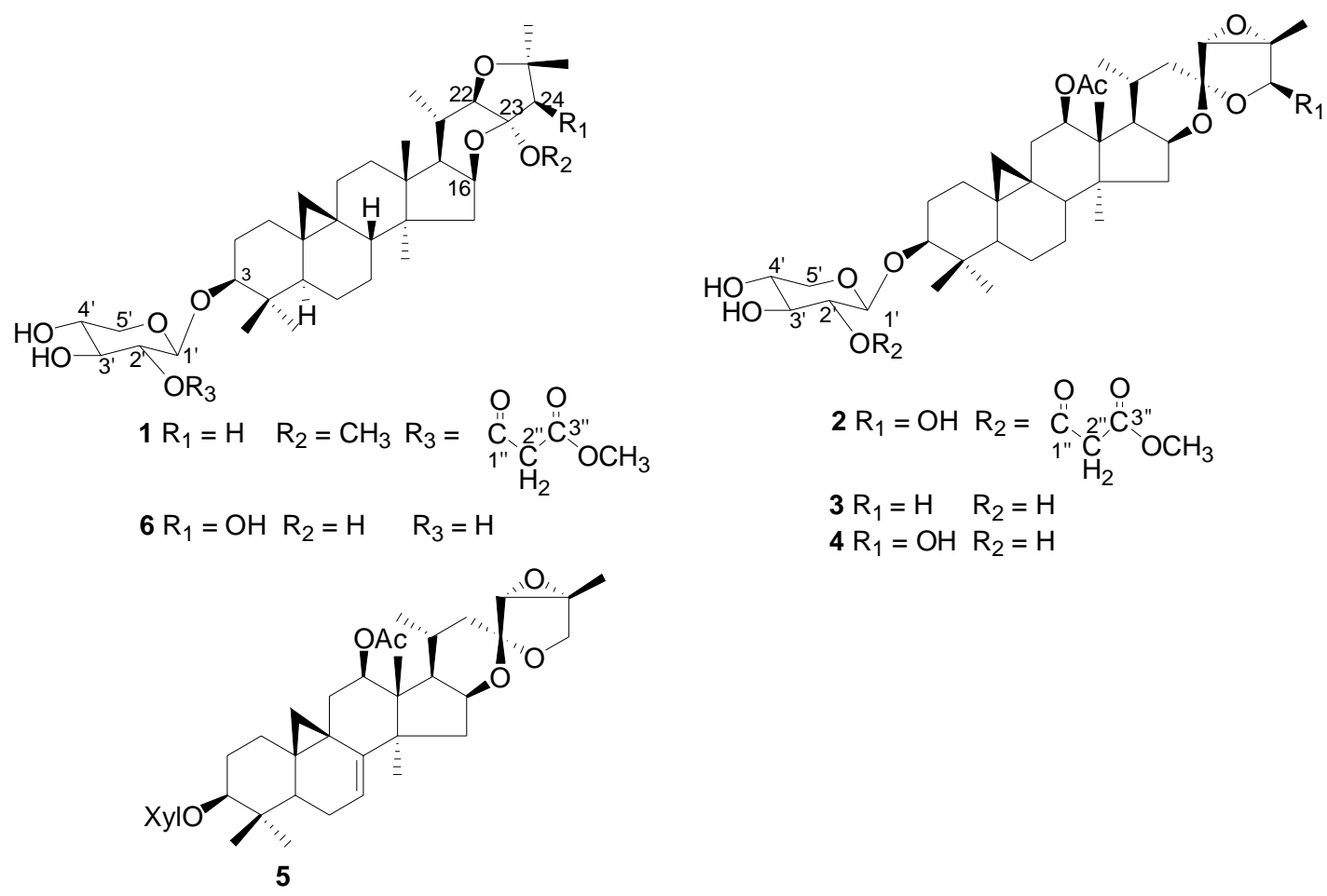

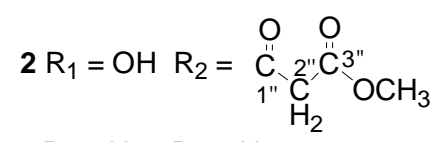$$
3 \mathrm{R}_{1}=\mathrm{H} \quad \mathrm{R}_{2}=\mathrm{H}
$$$$
4 \mathrm{R}_{1}=\mathrm{OH} \mathrm{R}_{2}=\mathrm{H}
$$

\section{Results and Discussion}

Compound 1 was isolated as a white powder. Its molecular formula was determined as $\mathrm{C}_{40} \mathrm{H}_{62} \mathrm{O}_{11}$ deduced from the negative HRFABMS $\left(\mathrm{m} / z 717.3146[\mathrm{M}-\mathrm{H}]^{-}\right.$, calcd. 717.3158 for $\left.\mathrm{C}_{40} \mathrm{H}_{61} \mathrm{O}_{11}\right)$ and the ${ }^{1} \mathrm{H}$ - and ${ }^{13} \mathrm{C}-\mathrm{NMR}$ spectra. The IR spectrum of 1 showed absorptions at 3,454, 1,728 and $1,211 \mathrm{~cm}^{-1}$ due to hydroxyl and carbonyl groups. The overall physical properties and NMR spectral profile suggested a cycloartane type of triterpene glycoside, a characteristic and distinguishable chemical marker of Cimicifuga plants [12]. The characteristic cyclopropane methylene signals at $\delta_{\mathrm{H}} 0.13$ and 0.39 (each $1 \mathrm{H}, \mathrm{d}, J=2.9 \mathrm{~Hz}$ ); six tertiary methyl groups at $\delta_{\mathrm{H}} 1.14$ (Me-18), 1.51 (Me-26), 1.61 (Me-27), 0.83 (Me-28), 1.30 (Me-29), 0.97 (Me-30) (each 3H, s), and one secondary methyl group at $\delta_{\mathrm{H}} 1.15(3 \mathrm{H}, \mathrm{d}, J=6.4 \mathrm{~Hz}, \mathrm{Me}-21)$; one methylene signal at $\delta_{\mathrm{H}} 3.78(2 \mathrm{H}, \mathrm{s}, \mathrm{H}-2 ")$; and two methoxyl groups at $\delta_{\mathrm{H}} 3.36(3 \mathrm{H}, \mathrm{s})$ and $\delta_{\mathrm{H}} 3.65(3 \mathrm{H}, \mathrm{s})$; and an anomeric proton at $\delta_{\mathrm{H}} 4.83(\mathrm{~d}, J=6.4 \mathrm{~Hz})$ were observed in the ${ }^{1} \mathrm{H}-\mathrm{NMR}$ spectrum (see Table 1). The ${ }^{13} \mathrm{C}-\mathrm{NMR}$ spectrum of $\mathbf{1}$ displayed 40 carbons, of which 30 carbons were ascribable to the triterpene aglycone, five carbons to a pentose residue at $\delta_{\mathrm{C}}$ 104.2 (C-1'), 76.8 (C-2'), 76.6 (C-3'), 71.3 (C-4'), 67.1 (C-5'), four carbons to one monomethyl 
malonate group at $\delta_{\mathrm{C}} 166.5(\mathrm{C}-1 "), 42.0(\mathrm{C}-2 "), 167.2(\mathrm{C}-3 ")$ and $52.3\left(3 "-\mathrm{O}^{\prime \prime} \mathrm{H}_{3}\right)$, and one carbons to one methoxyl at $\delta_{\mathrm{C}} 49.6\left(24-\mathrm{OCH}_{3}\right)$ (see Table 1). The NMR spectroscopic data of 1 showed great resemblance with those of 2'-O-malonylcimiaceroside B [16], except for the changes of C-3", C-23, $\mathrm{C}-24$, and the location of the monomethyl malonate group was also assigned to C-2' of the xylose unit in the following elucidation. First, all $\delta_{\mathrm{C}}$ and $\delta_{\mathrm{H}}$ of $\mathbf{1}$ were assigned by a detailed analysis of the HSQC spectrum. Then, in the HMBC spectrum, an informative correlation was observed between $\mathrm{H}-1$ ' of the anomeric signal at $\delta_{\mathrm{H}} 4.89$ and a $\mathrm{CH}$ signal at $\delta_{\mathrm{C}} 88.5(\mathrm{C}-3)$, suggesting that the sugar moiety was linked to C-3. After acid hydrolysis, only xylose was identified in the aqueous fraction by TLC comparison with an authentic sample, indicating the sugar unit in 1 was xylose. Moreover, the proton coupling constants of H-1' $(J=6.4 \mathrm{~Hz})$ suggested 1 had a $\beta$-D-xylopyranoside moiety, which was further supported by an obvious correlation between $\mathrm{H}-1^{\prime}\left(\delta_{\mathrm{H}} 4.89\right)$ of the xylose unit and H-3 $\left(\delta_{\mathrm{H}} 3.60\right)$ of the aglycon in the ROESY spectrum (Figure 2). A significant ROESY correlation between $\mathrm{H}-3$ and $\mathrm{H}-5$ suggested a $\beta$-orientation of the substituent group at $\mathrm{C}-3$. Furthermore, the location of the monomethyl malonate group could be unambiguously assigned to $\mathrm{C}-2^{\prime}$ of the xylose unit by HMBC, as a correlation was observed between $\mathrm{H}-2^{\prime}\left(\delta_{\mathrm{H}} 5.54, \mathrm{t}, J=6.9 \mathrm{~Hz}\right)$ and the carbonyl signal at $\delta_{\mathrm{C}} 166.5$. In the HMBC, two conspicuous correlations could also be observed between the methoxyl $\left(\delta_{\mathrm{H}} 3.65\right)$ and the carbonyl (C-3", $\left.\delta_{\mathrm{C}} 167.2\right)$, and between the methoxyl $\left(\delta_{\mathrm{H}} 3.36\right)$ and the hemiacetal $\left(\mathrm{C}-23, \delta_{\mathrm{C}}\right.$ 109.7), which suggested that the one methoxyl located the malonyl group to form a monomethyl malonate group, and another methoxyl was linked to $\mathrm{C}-23$. There was a notable difference at C-24 between compound 1 and 2'-O-malonylcimiaceroside B, namely a methine signal at C-24 in 2'-Omalonylcimiaceroside $\mathrm{B}$, while a methylene signal was observed at C-24 $\left(\delta_{C} 30.0, t\right)$ in compound $\mathbf{1}$, which was confirmed by HMBC correlations from $\delta_{\mathrm{H}} 1.54(\mathrm{~m}, \mathrm{H}-24)$ to $\delta_{\mathrm{C}} 109.7(\mathrm{~s}, \mathrm{C}-23)$ and to 83.4 (s, C-25). Thus, compound 1 was determined to be 23-O-methyl-24-deoxy-2'-O-(3"-methylmalonyl)cimiaceroside B, named cimiaceroside E.

Figure 2. The key HMBC and ROSEY correlations of $\mathbf{1 .}$

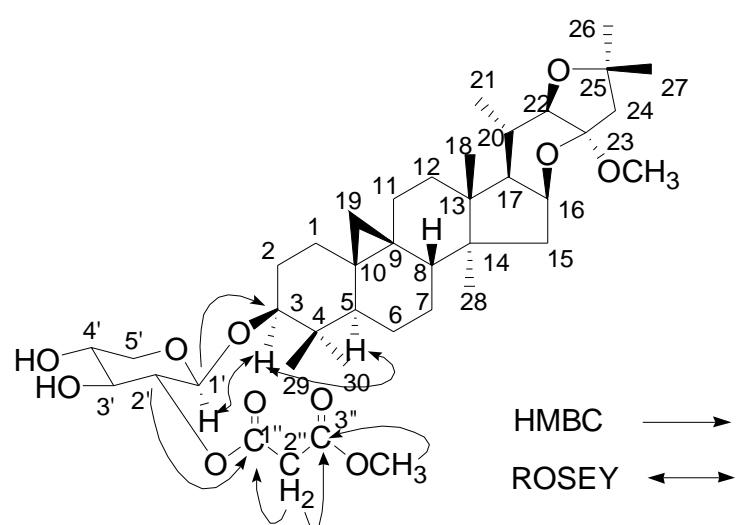


Table 1. The ${ }^{1} \mathrm{H}$ and ${ }^{13} \mathrm{C}-\mathrm{NMR}$ data of $\mathbf{1}$ and 2 in $\mathrm{C}_{5} \mathrm{D}_{5} \mathrm{~N}$ ( $\delta$ in ppm).

\begin{tabular}{|c|c|c|c|c|c|c|c|c|c|}
\hline \multirow[t]{2}{*}{ No } & \multicolumn{2}{|c|}{$\mathbf{1}^{\mathrm{a}}$} & \multicolumn{2}{|c|}{$2^{b}$} & \multirow[t]{2}{*}{ No } & \multicolumn{2}{|c|}{$1^{\mathrm{a}}$} & \multicolumn{2}{|c|}{$2^{b}$} \\
\hline & ${ }^{13} \mathrm{C}$ & ${ }^{1} \mathrm{H}$ & ${ }^{13} \mathrm{C}$ & ${ }^{1} \mathrm{H}$ & & ${ }^{13} \mathrm{C}$ & ${ }^{1} \mathrm{H}$ & ${ }^{13} \mathrm{C}$ & ${ }^{1} \mathrm{H}$ \\
\hline 1 & $32.0 \mathrm{t}$ & $1.20 \mathrm{~m} ; 1.52 \mathrm{~m}$ & $31.8 \mathrm{t}$ & $1.15 \mathrm{~m} ; 1.52 \mathrm{~m}$ & 20 & $34.3 \mathrm{~d}$ & $2.15 \mathrm{~m}$ & $26.0 \mathrm{~d}$ & $1.79 \mathrm{~m}$ \\
\hline 2 & $29.8 \mathrm{t}$ & $1.85 \mathrm{~m} ; 2.20 \mathrm{~m}$ & $29.7 \mathrm{t}$ & $1.88 \mathrm{~m} ; 2.28 \mathrm{~m}$ & 21 & $17.5 \mathrm{q}$ & $1.15 \mathrm{~d} 6.4$ & $21.0 \mathrm{q}$ & $0.94 \mathrm{~d} 6.3$ \\
\hline 3 & $88.5 \mathrm{~d}$ & 3.39 d 3.5 & $88.2 \mathrm{~d}$ & $3.31 \mathrm{dd} 4.5,11.5$ & 22 & $86.3 \mathrm{~d}$ & $3.67 \mathrm{~m}$ & $37.6 \mathrm{t}$ & $1.65 \mathrm{~m} ; 2.20 \mathrm{~m}$ \\
\hline 4 & $41.0 \mathrm{~s}$ & I & $40.9 \mathrm{~s}$ & / & 23 & $109.7 \mathrm{~s}$ & / & $105.8 \mathrm{~s}$ & / \\
\hline 5 & $47.3 \mathrm{~d}$ & $1.33 \mathrm{~m}$ & $46.9 \mathrm{~d}$ & $1.26 \mathrm{~m}$ & 24 & $30.0 \mathrm{t}$ & $1.54 \mathrm{~m}$ & $63.5 \mathrm{~d}$ & $3.90 \mathrm{~s}$ \\
\hline 6 & $20.9 \mathrm{t}$ & $0.73 \mathrm{~m} ; 1.31 \mathrm{~m}$ & $20.1 \mathrm{t}$ & $0.65 \mathrm{~m} ; 1.45 \mathrm{~m}$ & 25 & $83.4 \mathrm{~s}$ & / & $65.6 \mathrm{~s}$ & / \\
\hline 7 & $26.1 \mathrm{t}$ & $1.61 \mathrm{~m}$ & $25.7 \mathrm{t}$ & $0.95 \mathrm{~m} ; 1.30 \mathrm{~m}$ & 26 & $27.1 \mathrm{q}$ & $1.51 \mathrm{~s}$ & $98.4 \mathrm{~d}$ & $5.70 \mathrm{~s}$ \\
\hline 8 & $47.5 \mathrm{~d}$ & $1.49 \mathrm{~m}$ & $45.8 \mathrm{~d}$ & $1.52 \mathrm{~m}$ & 27 & $24.6 \mathrm{q}$ & $1.61 \mathrm{~s}$ & $13.1 \mathrm{q}$ & $1.74 \mathrm{~s}$ \\
\hline 9 & $19.7 \mathrm{~s}$ & I & $20.4 \mathrm{~s}$ & / & 28 & $19.7 \mathrm{q}$ & $0.83 \mathrm{~s}$ & $19.5 \mathrm{q}$ & $0.75 \mathrm{~s}$ \\
\hline 10 & $26.4 \mathrm{~s}$ & / & $26.7 \mathrm{~s}$ & / & 29 & $25.6 \mathrm{q}$ & $1.30 \mathrm{~s}$ & $25.6 \mathrm{q}$ & $1.08 \mathrm{~s}$ \\
\hline 11 & $26.5 \mathrm{t}$ & $1.79 \mathrm{~m}$ & $36.7 \mathrm{t}$ & $\begin{array}{l}1.16 \mathrm{~m} ; 2.68 \mathrm{dd} \\
8.3,15.9\end{array}$ & 30 & $15.2 \mathrm{q}$ & $0.97 \mathrm{~s}$ & $15.1 \mathrm{q}$ & $0.91 \mathrm{~s}$ \\
\hline 12 & $33.4 \mathrm{~d}$ & $1.50 \mathrm{~m}$ & $77.1 \mathrm{~d}$ & $5.05 \mathrm{dd} 3.7,8.5$ & $1^{\prime}$ & $104.2 \mathrm{~d}$ & $4.83 \mathrm{~d} 7.4$ & $104.1 \mathrm{~d}$ & $4.79 \mathrm{~d} 7.8$ \\
\hline 13 & $46.9 \mathrm{~s}$ & / & $48.7 \mathrm{~s}$ & / & $2^{\prime}$ & $76.8 \mathrm{~d}$ & $5.54 \mathrm{t} 6.9$ & $76.7 \mathrm{~d}$ & 5.50 t 8.4 \\
\hline 14 & $45.3 \mathrm{~s}$ & / & $47.8 \mathrm{~s}$ & / & $3^{\prime}$ & $76.6 \mathrm{~d}$ & $4.15 \mathrm{~m}$ & $76.1 \mathrm{~d}$ & $4.11 \mathrm{~m}$ \\
\hline 15 & $42.8 \mathrm{t}$ & $1.58 \mathrm{~m} ; 1.87 \mathrm{~m}$ & $43.6 \mathrm{t}$ & $\begin{array}{l}1.89 \mathrm{dd} 8.1,12.6 \\
1.71 \mathrm{~m}\end{array}$ & $4^{\prime}$ & $71.3 \mathrm{~d}$ & $4.18 \mathrm{~m}$ & $71.3 \mathrm{~d}$ & $4.15 \mathrm{~m}$ \\
\hline 16 & $72.5 \mathrm{~d}$ & $\begin{array}{l}4.40 \text { dd } 6.0, \\
12.5\end{array}$ & $73.0 \mathrm{~d}$ & $4.58 \mathrm{dd} 7.1,14.2$ & $5^{\prime}$ & $67.1 \mathrm{t}$ & $\begin{array}{l}3.64 \mathrm{~m} ; 4.29 \mathrm{dd} \\
3.5,8.7\end{array}$ & $67.1 \mathrm{t}$ & $\begin{array}{l}3.60 \mathrm{~m} ; 4.25 \mathrm{dd} \\
7.1,11.9\end{array}$ \\
\hline 17 & $51.6 \mathrm{~d}$ & $1.50 \mathrm{~m}$ & $56.4 \mathrm{~d}$ & $1.77 \mathrm{~m}$ & $1^{\prime \prime}$ & $166.5 \mathrm{~s}$ & / & $166.5 \mathrm{~s}$ & I \\
\hline 18 & $20.6 \mathrm{q}$ & $1.14 \mathrm{~s}$ & $13.6 \mathrm{q}$ & $1.33 \mathrm{~s}$ & $2^{\prime \prime}$ & $42.0 \mathrm{t}$ & $3.78 \mathrm{~s}$ & $42.0 \mathrm{t}$ & $3.74 \mathrm{~s}$ \\
\hline 19 & $30.2 \mathrm{t}$ & $\begin{array}{l}0.13 \text { d } 2.9 \\
0.39 \text { d } 2.9\end{array}$ & $29.6 \mathrm{t}$ & $\begin{array}{l}0.17 \mathrm{~d} 4.0 ; 0.50 \mathrm{~d} \\
4.0\end{array}$ & $3^{\prime \prime}$ & $167.2 \mathrm{~s}$ & I & $167.2 \mathrm{~s}$ & I \\
\hline
\end{tabular}

Note: ${ }^{\text {a }} 23-\mathrm{OCH}_{3}\left(\delta_{\mathrm{C}} 49.6, \mathrm{q} ; \delta_{\mathrm{H}} 3.36, \mathrm{~s}\right) ; 3$ "- $\mathrm{CH}_{3} \mathrm{O}\left(\delta_{\mathrm{C}} 52.3, \mathrm{q} ; \delta_{\mathrm{H}} 3.65, \mathrm{~s}\right) ;{ }^{\mathrm{b}} 12-\mathrm{COCH}_{3}\left(\delta_{\mathrm{C}} 170.6, \mathrm{~s}\right)$, $12-\mathrm{COCH}_{3}\left(\delta_{\mathrm{C}} 21.7, \mathrm{q} ; \delta_{\mathrm{H}} 2.12, \mathrm{~s}\right) ; 3 "-\mathrm{CH}_{3} \mathrm{O}\left(\delta_{\mathrm{C}} 52.3, \mathrm{q} ; \delta_{\mathrm{H}} 3.63, \mathrm{~s}\right)$.

Compound 2 was isolated as a white powder. The negative HR-FAB-MS of 2 showed a quasimolecular ion at $\mathrm{m} / \mathrm{z} 775.4365$, corresponding to the molecular formula of $\mathrm{C}_{41} \mathrm{H}_{60} \mathrm{O}_{14}$. The IR spectrum of 2 showed absorptions at 3,448, 2,500-3,000, 1,737 and 1,244 $\mathrm{cm}^{-1}$ due to hydroxyl and carbonyl groups. Its ${ }^{1} \mathrm{H}-\mathrm{NMR}$ spectrum (Table 1) exhibited characteristic cyclopropane methylene signals at $\delta_{\mathrm{H}} 0.17$ and 0.50 (each $\left.1 \mathrm{H}, \mathrm{d}, J=4.0 \mathrm{~Hz}\right)$; seven methyls at $\delta_{\mathrm{H}} 1.33(3 \mathrm{H}, \mathrm{s}, \mathrm{Me}-18), 0.94(3 \mathrm{H}$, d, $J=6.3 \mathrm{~Hz}, \mathrm{Me}-21), 5.70$ (3H, s, Me-26), 1.70 (3H, s, Me-27), 0.75 (3H, s, Me-28), 1.08 (3H, s, Me-29) and $0.91(3 \mathrm{H}, \mathrm{s}, \mathrm{Me}-30)$; Additionally, other signals for an anomeric proton at $\delta_{\mathrm{H}} 4.79(1 \mathrm{H}, \mathrm{d}$, $\left.J=7.8 \mathrm{~Hz}, \mathrm{H}-1^{\prime}\right)$, for an acetyl group at $\delta_{\mathrm{H}} 2.12(3 \mathrm{H}, \mathrm{s})$, and for a monomethyl malonate group at $\delta_{\mathrm{H}}$ $3.74(2 \mathrm{H}, \mathrm{s}, \mathrm{H}-2 ")$ and $\delta_{\mathrm{H}} 3.63(3 \mathrm{H}, \mathrm{s})$ were all observed. The ${ }^{13} \mathrm{C}-\mathrm{NMR}$ and DEPT spectra showed a total of 41 carbon signals, among which 30 carbons were ascribable to the triterpene aglycone, five carbons to a pentose residue, four carbons to a monomethyl malonate group, and two carbons to an acetyl group (see Table 1). A comparison of the ${ }^{1} \mathrm{H}$ - and ${ }^{13} \mathrm{C}-\mathrm{NMR}$ spectra of 2 with those of actein [13] revealed that 2 has an additional monomethyl malonate unit. Long-range correlations between $\delta_{\mathrm{H}} 4.79$ $\left(\mathrm{H}-1^{\prime}\right)$ and $88.6(\mathrm{C}-3)$, and between $\delta_{\mathrm{H}} 5.05(\mathrm{dd}, J=3.7,8.4 \mathrm{~Hz}, \mathrm{H}-12)$ and $170.6\left(12-\mathrm{COCH}_{3}\right)$ were observed in the HMBC spectrum of 2, which assigned the xylose linked at C-3 and the acetyl connected to $\mathrm{C}-12$, respectively. The xylose was also detected in the aqueous fraction of the acid 
hydrolysis products of $\mathbf{2}$. The additional monomethyl malonate unit was connected at C-2' of xylose, which could be confirmed by HMBC correlation between $\mathrm{H}-2^{\prime}\left(\delta_{\mathrm{H}} 5.50, \mathrm{t}, J=8.4 \mathrm{~Hz}\right)$ and the carbonyl signal at $\delta_{\mathrm{C}} 166.5$ (s, C-1") (see Figure 3). On the basis of the above evidence, the chemical structure of 2 was assigned as 2'-O-(3"-methylmalonyl)-actein, named cimifoside E.

Figure 3. The key HMBC correlations of 2.

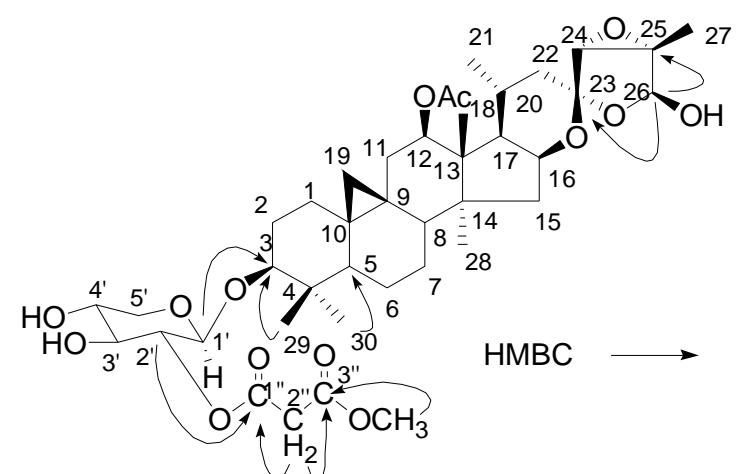

\section{Experimental}

\subsection{General}

Melting points were determined on a Mel-Temp II; Optical rotations were recorded on a Horiba SEPA-300 polarimeter; IR spectra were recorded on a Shimadzu IR-450 instrument, and are reported in $\mathrm{cm}^{-1}$; UV spectra were obtained in $\mathrm{MeOH}$ with a Shimadzu UV-2401A spectrometer, and absorption maxima are given in $\mathrm{nm} ;{ }^{1} \mathrm{H}-,{ }^{13} \mathrm{C}$-, and 2D-NMR spectra (all in $\mathrm{C}_{5} \mathrm{D}_{5} \mathrm{~N}$ ) were recorded with Bruker AV400 or DRX500 instruments, using TMS as an internal standard. Mass spectral data were recorded on a VG Autospec 3000 spectrometer. Silica gel (200-300 mesh, Qingdao Marine Chemical, P.R. China), Lichroprep RP-18 (40-63 um, Merck, Darmstadt, Germany) and Sephadex LH-20 (Pharmacia Fine Chemical Co., Ltd.) were used for column chromatography (CC). Fractions were monitored by TLC, and spots were visualized by heating TLC sprayed with $10 \% \mathrm{H}_{2} \mathrm{SO}_{4}$.

\subsection{Plant Material}

The rhizomes of $C$. foetida were collected in Lijiang, Yunnan Province, China, in June, 2003 and authenticated by Prof. Zong-Yu Wang (Kunming Institute of Botany, CAS). A voucher specimen (KUN No. 200308025) of the collection has been deposited at State Key Laboratory of Phytochemistry and Plant Resources in West China, Kunming Institute of Botany, the Chinese Academy of Sciences.

\subsection{Extraction and Isolation}

The dried, milled rhizomes of $C$. foetida $(23.4 \mathrm{~kg})$ were exhaustively extracted with $90 \% \mathrm{MeOH}$ (75 L) under reflux (4 times). The extract was evaporated under reduced pressure to yield a syrup-like residue (about $3.9 \mathrm{~kg}$ ). The syrup was suspended in $\mathrm{H}_{2} \mathrm{O}-\mathrm{MeOH}(9: 1)$, and extracted successively with EtOAc (15 L, 3 times, room temperature). The organic layer was dried (about $1.7 \mathrm{~kg}$ ), and then absorbed on silica gel $(2 \mathrm{~kg})$, and subjected to column chromatography eluting with a gradient system 
of $\mathrm{CHCl}_{3}-\mathrm{MeOH}$ from 0 to $100 \%$. The fractions were monitored by TLC, and combined to give seven fractions (Fr.1-7). Fr.2 (55 g), Fr.3 (152 g) contained abundant triterpenoids by TLC examination, indicating the two fractions were worthy of further investigation. Fr. 2 was rechromatographed on a column (silica gel, $\mathrm{CHCl}_{3}-\mathrm{MeOH} 100: 1,80: 1,65: 1,50: 1$ ) to obtain subfraction Fr.2.1, containing compounds $3(15 \mathrm{mg})$ and $4(79 \mathrm{mg})$. The subfraction 2.1 was subjected to $\mathrm{RP}_{-} \mathrm{C}_{18}$ by using $\mathrm{MeOH}-\mathrm{H}_{2} \mathrm{O}$ (80:20) as mobile phase to give compounds 1 and 2. Fr. 3 was subjected to CC (silica gel, $\mathrm{CHCl}_{3}-\mathrm{MeOH}$ 30:1, 20:1, 10:1 gradient ) and further purified by Sephadex LH-20 with eluting MeOH to give $5(76 \mathrm{mg})$ and $6(43 \mathrm{mg})$.

Cimiaceroside E (1). white powder; m.p. $172{ }^{\circ} \mathrm{C} ;[\alpha]_{\mathrm{D}}^{27}-25.0^{\circ}\left(c=0.80, \mathrm{CHCl}_{3}\right.$ : $\left.\mathrm{EtOH}(1: 1)\right)$; negative FABMS $m / z(\%) 717[\mathrm{M}-\mathrm{H}]^{-}$(8), 689 (25), 118 (43), $601[\mathrm{M}-117]^{-}$(4) and $117\left[\mathrm{C}_{3} \mathrm{H}_{7} \mathrm{O}_{4}\right]^{-}$(44); negative HRFABMS $(\mathrm{m} / z \text { 717.3146 [M-H] }]^{-}$, calcd. 717.3158 for $\left.\mathrm{C}_{40} \mathrm{H}_{61} \mathrm{O}_{11}\right)$; IR $(\mathrm{KBr}) v_{\max } 3454$, 2957, 2927, 2870, 1728, 1631, 1442, 1381, 1366, 1339, 1211, 1172, 1072, 1052, 971, 897, 820, 633, $583,537 \mathrm{~cm}^{-1} .{ }^{1} \mathrm{H}-\mathrm{NMR}\left(500 \mathrm{MHz}, \mathrm{C}_{5} \mathrm{D}_{5} \mathrm{~N}\right)$ and ${ }^{13} \mathrm{C}-\mathrm{NMR}$ data $\left(100 \mathrm{MHz}, \mathrm{C}_{5} \mathrm{D}_{5} \mathrm{~N}\right)$ see Table 1.

Cimifoside $E$ (2). white powder; m.p. $168-179{ }^{\circ} \mathrm{C}$; $[\alpha]_{\mathrm{D}}^{27}-45.5^{\circ}\left(c=1.10, \mathrm{CHCl}_{3}\right.$ : EtOH (1:1)); negative FABMS $m / z 775[\mathrm{M}-\mathrm{H}]^{-}, 662[\mathrm{M}-103]^{-}$and $104\left[\mathrm{C}_{3} \mathrm{H}_{4} \mathrm{O}_{4}\right]^{-}$; negative HRFABMS $(\mathrm{m} / \mathrm{z}$ $775.4365[\mathrm{M}-\mathrm{H}]^{-}$, calcd. 775.4382 for $\left.\mathrm{C}_{41} \mathrm{H}_{59} \mathrm{O}_{14}\right)$; IR (KBr) $v_{\max } 3455,2953,1760,1737,1457,1440$, 1369, 1348, 1244, 1204, 1163, 1075, 1042, 1024, 984, 831, 726, 633, 604, $540 \mathrm{~cm}^{-1}$. ${ }^{1} \mathrm{H}-\mathrm{NMR}$ $\left(500 \mathrm{MHz}, \mathrm{C}_{5} \mathrm{D}_{5} \mathrm{~N}\right)$ and ${ }^{13} \mathrm{C}-\mathrm{NMR}$ data $\left(100 \mathrm{MHz}, \mathrm{C}_{5} \mathrm{D}_{5} \mathrm{~N}\right)$ see Table 1.

\subsection{Acid Hydrolysis of Compounds 1, 2}

Compounds 1 and 2 (6 mg of each) were refluxed with 5\% $\mathrm{HCl}$ in $\mathrm{MeOH}(7 \mathrm{~mL})$ for $8 \mathrm{~h}$. Each mixture was diluted with $\mathrm{H}_{2} \mathrm{O}$ and neutralized with $\mathrm{NaHCO}_{3}$. The neutral hydrolysate revealed the presence of only xylose by TLC (n-BuOH-AcOH- $\mathrm{H}_{2} \mathrm{O}, 4: 1: 1, \mathrm{R}_{\mathrm{f}}=0.4$ ) upon comparison with the authentic sample.

\section{Conclusions}

Due to their medicinal uses, chemical constituents of Cimicifuga species have been extensively studied by several groups [7,12,17]. To date, more than 200 triterpenes have been isolated from the genus [4,18]. In our continuing studies, new compounds had still been found. In this paper, new triterpene glycosides with a monomethyl malonate group rarely found in the genus Cimicifuga were identified.

\section{Acknowledgements}

The project was financially supported by the Knowledge Innovation Program of the CAS (Grant No. KSCX2-YW-G-038, KSCX2-EW-R-15, KSCX2-YW-R-194, KSCX2-YW-R-29 and KZCX2XB2-15-03), Foundation of State Key Laboratory of Phytochemistry and Plant Resources in West China (P2008-ZZ05 and P2010-ZZ14). 


\section{References}

1. Lieberman, S.J. A review of the effectiveness of Cimicifuga racemosa (black cohosh) for the symptoms of menopause. Women's Health 1998, 7, 525-529.

2. Mckenna, D.J.; Jones, K.; Humphrey, S.; Hughes, K. Black cohosh: Efficacy, safety, and use in clinical and preclinical applications. Altern. Ther. 2001, 7, 93-100.

3. Liske, E.; Wustenberg, P. Therapy of climacteric complaints with Cimicifuga racemosa: herbal medicine with clinically proven evidence. Menopause 1998, 5, 250-256.

4. Lin, Y.P.; Qiu, M.H.; Li, Z.R. Studies on the chemical constituents and biologic activities of Cimicifuga. Nat. Prod. Res. Dev. 2002, 14, 58-76.

5. Qiu, M.H.; Kim, J.H.; Lee, H.K.; Min, B.S. Anticomplement activity of cycloartane glycosides from the rhizome of Cimicifuga foetida. Phytother. Res. 2006, 20, 945-948.

6. Sun, L.R.; Yan, J.; Pei, S.J.; Qiu, M.H. A new cycloartane triterpenoid from the rhizome of Cimicifuga foetida collected in Dali. Acta Bot. Yunnan 2005, 27, 331-336.

7. Sun, L.R.; Qing, C.; Zhang, Y.L.; Jia, S.Y.; Li, Z.R.; Pei, S.J.; Qiu, M.H.; Michael, L.G.; Qiu, S.X. Cimicifoetisides A and B, two cytotoxic cycloartane triterpenoid glycosides from the rhizomes of Cimicifuga foetida, inhibit proliferation of cancer cells. Beilstein J. Org. Chem. 2007, 3, No. 3.

8. Sun, L.R.; Yan, J.; Lu, L.; Pei, S.J.; Li, Z.R.; Zhou, L.; Zhang, X.M.; Qiu, M.H. Cimicifine A: A novel triterpene alkaloid from the rhizomes of Cimicifuga foetida. Helv. Chim. Acta 2007, 7, 1313-1318.

9. Sun, L.R.; Yan, J.; Nian, Y.; Zhou, L.; Zhang, H.J.; Qiu, M.H. New triterpene diglycosides from the rhizome of Cimicifuga foetida. Molecules 2008, 13, 1712-1721.

10. Lu, L.; Chen, J.C.; Nian, Y.; Sun, Y.; Qiu, M.H. Trinor-cycloartane glycosides from the rhizomes of Cimicifuga foetida. Molecules 2009, 14, 1578-1584.

11. Nian, Y.; Zhang, Y.L.; Chen, J.C.; Lu, L.; Qiu, M.H.; Qing, C. Cytotoxic chemical constituents from the roots of Cimicifuga fetida. J. Nat. Prod. 2010, 73, 93-98.

12. Chen, S.N.; Li, W.K.; Fabricant, D.S.; Santarsiero, B.D.; Mesecar, A.; Fitzloff, J.F.; Fong, H.H.S.; Farnsworth, N.R. Isolation, structure elucidation, and absolute configuration of 26-deoxyactein from Cimicifuga racemosa and clarification of nomenclature associated with 27-deoxyactein. J. Nat. Prod. 2002, 65, 601-605.

13. Li, C.J.; Li, Y.H.; Chen, S.F.; Xiao, P.G. Triterpenoids from Cimicifuga foetida L. Acta Pharm. Sin. 1994, 29, 449-453.

14. Kusano, A.; Takahira, M.; Shibano, M.; Miyase, T.; Kusano, G. Studies on the constituents of Cimicifuga species. XXVI. Twelve new cyclolanostanol glycosides from the underground parts of Cimicifuga simplex Wormsk. Chem. Pharm. Bull. 1999, 47, 511-516.

15. Kusan, A.; Yakahira, M.; Shibano, M.; Miyase, T.; Okuyama, T.; Kusano, G. Structures of two new cyclolanostanol xylosides: cimiacerosides A and B. Heterocycles 1998, 48, 1003-1014.

16. Kusano, A.; Shibano, M.; Kusano, G. Studies on the constituents of Cimicifuga species. XXVII. Malonyl cyclolanostanol glycosides from the underground parts of Cimicifuga simplex Wormsk. Chem. Pharm. Bull. 1999, 47, 1175-1179.

17. Liu, Y.; Chen, D.H.; Si, J.Y.; Tu, G.Z.; An, D.G. Two new cyclolanostanol xylosides from the aerial parts of Cimicifuga dahurica. J. Nat. Prod. 2002, 65, 1486-1488. 
18. Li, J.X.; Yu, Z.Y. Cimicifugae rhizoma: from origins, bioactive constituents to clinical outcomes. Curr. Med. Chem. 2006, 13, 2927-2951.

Sample Availability: Samples of the compounds 1-6 are available from the authors.

(C) 2011 by the authors; licensee MDPI, Basel, Switzerland. This article is an open access article distributed under the terms and conditions of the Creative Commons Attribution license (http://creativecommons.org/licenses/by/3.0/). 